\title{
Полиморфизм локусов митохондриальной ДНК у образцов картофеля, отличающихся по признаку мужской фертильности/ стерильности и обладающих разными типами цитоплазм
}

\author{
О.Ю. Антонова ${ }^{1 *}$, Н.В. Алпатьева ${ }^{1}$, К.В. Егорова ${ }^{1,2}$, Н.С. Клименко ${ }^{1}$, \\ Ю.И. Карабицина ${ }^{1}$, Т.А. Гавриленко ${ }^{1,2}$ \\ ${ }^{1}$ ФИЦ Всероссийский институт генетических ресурсов растений имени Н.И. Вавилова (ВИР), \\ Санкт-Петербург, Россия \\ ${ }^{2}$ Санкт-Петербургский государственный университет, Санкт-Петербург, Россия \\ *e-mail: olgaant326@mail.ru
}

В работе изучен полиморфизм локусов митохондриального генома у сортов и селекционных клонов картофеля, имеющих, согласно классификации Hosaka, Sanetomo (2012), стерильные (T/beta, W/gamma, D = W/alpha) и фертильный (P/beta) типы цитоплазм. Материал был фенотипирован по признаку фертильности/ стерильности пыльцы.

Методом секвенирования были проанализированы участки генов, которые, согласно литературным данным, могут быть связаны с цитоплазматической мужской стерильностью (ЦМС), а именно: гены АТФ-синтаз (atp6, atp9), интроны генов nad2, nad7, cox2, CcmFc, rps3 и межгенный спейсер nad1/atp6. Данные последовательности идентифицированы нами в неаннотированном митохондриальном геноме Solanum phurea (https://www.ncbi.nlm.nih.gov/nuccore/ JF772172.1). Для их амплификации было разработано 11 пар праймеров, ПЦРпродукты были секвенированы на приборе АBI 3500x1 в ЦКП «Геномные технологии и клеточная биология» (ФГБНУ ВНИИСХМ). Независимо от типа цитоплазмы образцов, участки генов nad2, nad7, cox 2, rps3 и atp6 были идентичны друг другу и референсной последовательности JF772172.1. В межгенном спейсере nad1/ atp6 обнаружен один полиморфный сайт (замена $\mathrm{G} \rightarrow \mathrm{T}$ ), позволяющий отличать образцы с beta-типом мт-ДНК. Последовательность мт-локуса atp 9 у изученных генотипов была представлена несколькими вариантами, отличавшимися друг от друга 1-17 заменами. У селекционного клона NV20 (gamma-тип мтДНК) выявлен «усеченный» вариант последовательности гена $C c m F c$ - фрагмент длиной 687 п. о., тогда как основной амликон имел длину 2016 п.о. Обнаруженные отличия не оказывали влияния на признак фертильности пыльцы.

Дополнительно был проанализирован локус $\operatorname{rps} 14 / \mathrm{cob}$, в котором ранее методом ПДРФ анализа были выявлены фрагменты, специфичные для стерильного W/gamma типа цитоплазмы. С помощью разработанных нами полиморфных CAPSмаркеров показано отсутствие полиморфизма в данном локусе у 202 образцов с alpha- и beta- типами мтДНК - все они относились к одному митотипу pumD1. В то же время, 26 сортов с тетрадной мужской стерильностью (цитоплазма W/gamma), разделились на 14 митотипов. Объяснением высокого полиморфизма локуса $r p s 14 / c o b$ у сортов с цитоплазмой W/gamma могут быть перестройки в мтДНК, происходящие при межвидовой гибридизации. Дальнейшие исследования будут связаны с секвенированием выявленных полиморфных вариантов локуса rps 14/cob. Благодарности: Работа выполнена при поддержке гранта РНФ № 16-16-04125. 